\title{
A (DES)CONSTRUÇÃo dA PRÁTICA PEDAGógICA NA EDUCAÇÃo DO CAMPO: O DIÁLOGO ENTRE O SABER POPULAR \\ E O SABER CIENTÍFICO
}

\author{
THE (DE)CONSTRUCTION OF PEDAGOGICAL PRACTICE IN FIELD \\ EDUCATION: THE DIALOGUE BETWEEN POPULAR KNOWLEDGE \\ AND SCIENTIFIC KNOWLEDGE
}

\author{
Conceição Clarete Xavier Travalha ${ }^{1}$ \\ Leila de Cassia Faria Alves ${ }^{2}$
}

\begin{abstract}
RESUMO
Construída com o protagonismo dos movimentos sociais camponeses, a Educação do Campo se tornou um dos mais importantes mecanismos de transformação social, via educação, desenvolvidos no Brasil nas duas últimas décadas. O diálogo entre os movimentos sociais e a universidade vem permitindo novas formas de se conceber a educação como instrumento de emancipação dos povos do campo. As motivações deste artigo originaram-se de inquietações e preocupações geradas no contexto da formação de professores no âmbito da Educação do Campo. O nosso objetivo foi refletir acerca do diálogo entre a ciência oficial constituída e os saberes populares a partir da descrição de uma prática pedagógica construída numa escola do campo. Os resultados evidenciaram que o diálogo entre esses saberes é algo real nas escolas do campo, possível no universo acadêmico e imprescindível nas diversas esferas que compõem o universo educativo das escolas do campo.
\end{abstract}

Palavras-chave: Educação do Campo. Desconstrução. Práticas Pedagógicas.

\footnotetext{
1 Pós-doutorado na área de estudos de Educação, Complexidade e transdisciplinaridade em Cuba na Universidade de Holguim e Pós-doutorado em Educação e Espiritualidade na UFPE Doutorado em Educação pela Universidade Estadual de Campinas (2004). Mestrado em Educação pela Universidade Federal de Minas Gerais (1992). Graduação em Psicologia pela Universidade Federal de Minas Gerais (1988) e graduação em Física pela Universidade Federal de Minas Gerais (1978). Atualmente é Professora associada do Departamento de Ciências Aplicadas à Educação da Universidade Federal de Minas Gerais. Coordena o Núcleo de Estudos e pesquisas do Pensamento Complexo NEPPCOM /UFMG .
}

${ }^{2}$ Professora Assistente do Instituto de Engenharia, Ciência e Tecnologia da Universidade Federal dos Vales do Jequitinhonha e Mucuri. Mestra em Educação pela Faculdade de Educação da Universidade Federal de Minas Gerais e Licenciada em Ciências/Matemática pela Universidade do Estado de Minas Gerais. Interessa-se, sobretudo, pelos seguintes temas: transdisciplinaridade, etnomatemática, desconstrução, combate às desigualdades sociais e epistêmicas, movimentos sociais, direitos humanos e educação emancipatória. 


\begin{abstract}
Constructed with the protagonism of the peasant social movements, the Education of the Field has become one of the most important mechanisms of social transformation, through education, developed in Brazil in the last two decades. The dialogue between the social movements and the university has allowed new ways of conceiving education as an instrument of emancipation of the rural people. The motivations of this article stemmed from concerns and concerns generated in the context of teacher education in the Field Education. Our objective was to reflect on the dialogue between the established official science and the popular knowledge from the description of a pedagogical practice built in a country school. The results showed that the dialogue between these knowledge is real in the rural schools, possible in the academic universe and indispensable in the various spheres that make up the educational universe of the rural schools.
\end{abstract}

Keywords: Field Education. Deconstruction. Pedagogical practices.

\title{
INTRODUÇÃO
}

A tarefa do educador consciente de sua função social não é apenas a de transferir os conteúdos científicos e escolares para os alunos, mas sim a de construir, com a participação deles, o conhecimento e a cidadania. No entanto, Paulo Freire (2000) observa que historicamente no Brasil o caráter socializante e humanístico do processo de construção do conhecimento foi entendido como um simples ato de transferência de saber.

Essa constatação freiriana suscita a seguinte questão: até que ponto essa concepção de ensino-aprendizagem, tributária de uma compreensão estreita do significado do que é educação e do que é aprender, foi responsável pela separação hierárquica entre as disciplinas e pela dissociação entre o conhecimento adquirido no universo escolar e acadêmico com aquele vivenciado no cotidiano dos sujeitos, das comunidades e dos movimentos?

Bem sabemos que o trabalho de compreensão dessa problemática é muito extenso. Logo, para chegarmos a um denominador comum, seria necessário refletirmos acerca dos métodos de construção de conhecimento adotados na totalidade dos processos de formação de professores. Assim, dentre a diversidade de enfoques existentes e por tratarmos especificamente neste trabalho dos processos formativos ocorridos nos territórios da Educação do Campo, atemo-nos à crítica ao modelo tradicional e hegemônico, cuja produção de saber fora pautada na rigidez disciplinar, marcada pela assimilação dos conteúdos científicos e pelo distanciamento entre os sujeitos que ensinam e aprendem. 
Longe de ter sido superado por completo, esse modelo antidemocrático de formação docente inibia o sujeito de se assumir como ser capaz de propor alternativas e ações em realidades escolares específicas - como aquelas apresentadas pelas escolas do campo -, pois o processo formativo visava única e exclusivamente à transferência dos conhecimentos curriculares. Pensada a partir de uma lógica diferente, a Educação do Campo propõem a construção coletiva dos conhecimentos, de modo que o educador consciente de seu papel deve assumir não somente uma postura de compromisso com os conteúdos curriculares, mas, sobretudo, buscar adequá-los às especificidades surgidas no cotidiano docente.

Nessa perspectiva, buscamos neste texto discutir a construção de uma prática pedagógica pensada segundo os princípios da Educação do Campo, isto é, com a participação dos estudantes e valorizando as experiências partilhadas nos territórios educativos ocupados pelas escolas do campo do Vale do Jequitinhonha, região nordeste de Minas Gerais. Para tanto, apresentamos abaixo as bases epistemológicas que nortearam nosso trabalho, seguidas da metodologia, da análise e das considerações finais.

\section{DISCUSSÃO TEÓRICA}

Nas críticas que fez ao paradigma hegemônico de formação docente, Paulo Freire argumentou que no processo de construção do conhecimento "a aprendizagem da assunção do sujeito é incompatível com o treinamento pragmático ou com o elitismo autoritário dos que se pensam donos da verdade e do saber articulado" (FREIRE, 2000, p. 47). Decerto, Freire alertou-nos que a interação entre educadores e educandos possui elementos subjetivos e afetivos, pois sendo a construção do saber um processo precário e inacabado, as emoções e os sentimentos se mesclam à diversidade de situações e de perspectivas que os interlocutores partilham no intercâmbio de experiências mediado pelo trabalho docente.

Depreende-se, assim, que o risco e o afeto são características inerentes aos processos educativos que buscam não apenas transferir, mas, sobretudo, criar condições democráticas de produção e de construção do conhecimento, pois o processo de construção do saber, além de ser dinâmico, é complexo (UDE, 2014).Para Morin (2002), essa questão ocorre porque ao passo que o ser humano é múltiplo, existe a sua estrutura mental que faz parte da 
complexidade humana, isto é, ou vemos a unidade do gênero e esquecemos a diversidade das culturas, dos indivíduos, ou vemos a diversidade das culturas e não vemos a unidade do ser humano (MORIN, 2002).

Por esse viés, percebemos que no interior dos processos educativos que tangenciam a formação do professor do campo, o diálogo entre os conhecimentos científicos e os saberes advindos do cotidiano das comunidades e dos sujeitos que produzem suas condições materiais e históricas de existência nas zonas rurais favorece o surgimento de práticas pedagógicas contextualizadas à realidade dos educandos e das comunidades.

No âmbito da formação universitária de professores, esse movimento de interação é importante no avanço e democratização do saber articulado, pois permite que disciplinas historicamente separadas pela especialização e pela divisão social do trabalho conversem entre si. Além de ser um importante mecanismo de inclusão dos saberes e dos conhecimentos populares, que por se organizarem fora dos sistemas de representação valorizados pela ciência moderna, não obtiveram o devido reconhecimento por parte do paradigma hegemônico.

$\mathrm{Na}$ verdade, bem sabemos que por longos anos os saberes populares foram relegados, pois a intenção das elites era reformar e reeducar o povo através da difusão maciça da ideologia da classe dominante. Os projetos educativos refletiam as relações entre exploradores e explorados, pois a subordinação das classes populares à lógica tecnicista embutida nesses dispositivos era dissimulada "por uma ideologia da Escola universalmente aceita (...) que representa a Escola como neutra, desprovida de ideologia" (ALTHUSSER, 2010, p. 80).

Mas não há neutralidade na educação. Pelo contrário, esse campo de forças ideológicas tem sido usado historicamente pelas elites dirigentes para exercer o controle social e impor os interesses do sistema capitalista. A prova disso é que quando analisamos a narrativa da educação brasileira deparamos com uma gama de projetos e ações governamentais concebidas de forma vertical e sem a participação dos sujeitos envolvidos nos processos educativos que buscavam no mínimo dois objetivos bem delineados: formar mão- 
de-obra qualificada ao mercado de trabalho e transformar a população num corpo dócil, capaz de obedecer e de ser dominada pelo discurso do mercado ${ }^{3}$.

A visão dominante dessas intervenções estatais na área da educação pouco considerava a formação política e humanística do sujeito, afastando com o pragmatismo pedagógico e o treinamento técnico-científico que lhes são característicos, a capacidade de os indivíduos transformarem a realidade que os rodeia. Além disso, nos currículos o diálogo entre os conhecimentos populares e o conhecimento científico permaneceu interditado por ideologias que colocavam o saber articulado por especialistas em relação de superioridade quando comparado aos saberes oriundos das camadas subalternas da sociedade.

Em outras palavras, a escola é uma instituição que canaliza e reproduz as ideologias disseminadas no duelo de forças travado em torno do funcionamento da sociedade. E por serem arenas de consentimento e resistência, esses espaços de distribuição simbólica tornamse lugares onde a transformação social pode ser pensada e ensaiada. Todavia, conforme salienta HALL (2011), ao policiar, regular e disciplinar os conhecimentos produzidos pelas sociedades modernas, diversas e multiculturais como a brasileira,

a escola e o sistema educacional são exemplos de instituições que distinguem a parte valorizada da cultura, a herança cultural, a história a ser transmitida, da parte "sem valor". O aparato acadêmico e literário é outro que distingue certos tipos valorizados de conhecimento de outros (HALL, 2003, p. 257).

Considerando esse aspecto, percebe-se que ao valorizar certos tipos de conhecimento em detrimento de outros, o sistema educacional brasileiro sustentou uma lógica perversa de formação acrítica dos indivíduos. Por isso o avanço na luta pelo reconhecimento e efetivação da educação como um direito tem sido travada pelos sujeitos coletivos justamente nos campos da cultura e da política, territórios onde não há vitórias definitivas, e sim posições a serem constantemente conquistadas ou perdidas.

$\mathrm{Na}$ Educação do Campo, por exemplo, é consenso que as práticas pedagógicas precisam reconhecer e valorizar os saberes populares presentes nas práticas sociais dos grupos

\footnotetext{
${ }^{3}$ É o que ocorreu, por exemplo, no regime militar com o MOBRAL e recentemente com o Reinventando o Ensino Médio, política dos governos neoliberais implantada nas escolas de Minas Gerias nesta década.
} 


\section{Revista
Debates Insubmissos}

minoritários - quilombolas, assentados, agricultores familiares, extrativistas, ribeirinhos e tantos outros que tem como condição básica de existência o ato viver no campo.

De fato, um olhar descentrado para os saberes partilhados por esses grupos revela a existência de formas de organização política e cultural que se encontram fora dos territórios ocupados pela ciência moderna e pela razão cartesiana. Contudo, o fato de os conhecimentos partilhados nesses contextos estarem do lado de fora da escola e da universidade não quer dizer que estejam do lado oposto àquele ocupado pelo saber científico. O que há são hierarquias concebidas em torno das diversificadas formas de conhecimento que precisam ser constantemente questionadas, confrontadas e complementadas com o valor da experiência coletiva das comunidades e dos movimentos.

Portanto, em um plano geral, apregoa-se nos territórios educativos da Educação do Campo que na construção do conhecimento as práticas pedagógicas advindas da interação entre os distintos polos do saber não podem mais ser ensaiadas sob a égide de categorias antagônicas de agenciamento, como historicamente foi determinado pelo discurso tradicional e hegemônico através de oposições binárias que legitimam a hierarquia e a supremacia da razão cartesiana, como ocorre nos seguintes pares: povo $\mathrm{x}$ elite, popular $\mathrm{x}$ científico, civilizado x primitivo, homem x mulher, branco x negro, centro x periferia, original x cópia, campo x cidade, rural x urbano.

Por essa lógica, fica evidente que dentre as muitas formas de exclusão reproduzidas pelo aparelho educativo, uma das mais latentes é a relação de desigualdade no valor atribuído ao conhecimento teórico dos especialistas em contraposição à prática e à experiência dos grupos cujos saberes não detêm a legitimação que possui o saber articulado. E essa relação de desigualdade, convém ressaltar, é inerente ao valor assumido pelos sujeitos na estrutura hierárquica e vertical de ocupação dos espaços sociais.

Em um plano geral, podemos dizer com as palavras de Lino Gomes (2010) que historicamente no Brasil a diferença foi construída e transformada em desigualdade "nas relações políticas, nos padrões de poder, de trabalho, na apropriação da terra, do espaço urbano, do conhecimento, da linguagem, da ciência, da tecnologia e da vida coletiva" (GOMES, 2010, p.05). 


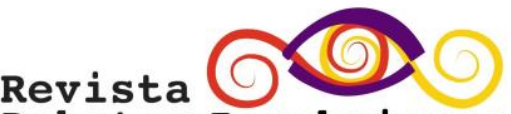 \\ Debates Insubmissos}

Nessa perspectiva, entendemos que se a desigualdade foi construída nas relações de poder tecidas no interior das transformações sociais, econômicas e políticas pelas quais passou o país, a configuração hierárquica dos saberes pode ser subvertida no processo de mediação do conhecimento por meio de práticas pedagógicas alicerçadas na experiência dos educandos e das comunidades. Logo, reconhecer as assimetrias existentes entre a fala e a ação dos discursos proferidos pelas vozes autorizadas dos especialistas torna-se o primeiro passo para a democratização do conhecimento e abertura definitiva da escola e da universidade para a pluralidade de sujeitos e objetos que compõem a sociedade brasileira.

Em outras palavras, a gênese histórica das contradições sociais provém do modelo de construção do país, fortemente marcado pela imposição de valores e modelos transplantados dos grandes centros econômicos e culturais para a realidade nacional. E por ter se estruturado de modo orgânico no país, essa percepção da realidade, centrada nos valores estrangeiros e alheia à realidade de grande parte dos brasileiros, permanece ainda hoje incrustrada nos espaços, nas relações de poder e nas práticas socioculturais, gerando mecanismos de exclusão, reproduzidos, sobretudo, pelas instituições educativas que promovem a distribuição simbólica dos bens culturais.

No entanto, de acordo com Chauí (2012), o problema da desigualdade não está circunscrito ao aparelho educativo, porque toda a sociedade brasileira é caracterizada pela ocupação hierárquica do espaço social, com as diferenças e assimetrias sendo transformadas em desigualdades naturais que legitimam e reforçam a hegemonia de alguns grupos sobre outros. No decorrer dos tempos, assim aconteceu, por exemplo, com a escravização dos negros e extermínio dos indígenas, com o patriarcado e com a repressão às minorias sexuais e camponesas.

De modo que, no Brasil,

[...] quando a desigualdade é muito marcada, a relação social assume a forma nua da opressão física e/ou psíquica. A divisão social das classes é naturalizada por um conjunto de práticas que ocultam a determinação histórica ou material da exploração, da discriminação e da dominação, e que, imaginariamente, estruturam a sociedade sob o signo da nação una e indivisa, sobreposta como um manto protetor que recobre as divisões reais que a constituem (CHAUÍ, 2012, p.93). 
Dentre outras razões que justificam a desigualdade, do ponto de vista histórico, a filósofa ressalta ainda que a construção da ordem colonial e monárquica sustentada pelo modo de produção escravista pautado na relação não dialética mando-obediência, no período republicano permaneceu no imaginário nacional ressignificada nos privilégios de classe, gênero e raça que hoje em dia ameaçam não só a efetividade dos direitos individuais e coletivos, mas a democracia como um todo.

Nessa perspectiva, inferimos que, por certo, a disposição da sociedade brasileira proporciona dificuldades para a efetivação de direitos civis fundamentais, como o acesso universal à educação. Como sabemos, esse direito humano vai além dos muros da escola. Ele abarca todos os espaços de existência, tornando-se um dos pilares de construção e concretização da igualdade social. E se a sociedade é desigual, a tendência é a de que a educação dispensada aos seus membros exprima e legitime as relações hierárquicas entre classes e grupos, afastando os sujeitos que não possuem os privilégios construídos historicamente, do acesso aos direitos e, por conseguinte, da cidadania.

Contudo, compreender como se processa a reprodução da desigualdade nos espaços de ensino-aprendizagem exige que pensemos para além da questão histórica, pois a atual configuração da sociedade brasileira tem mostrado que a naturalização das assimetrias sociais tem sido construída a partir de novas e modernas formas de dominação. E esses meios modernos de manutenção das ideologias dominantes, ao passo que são distintos das antigas formas de opressão, cumprem a mesma função de antes, porque na prática têm igual intencionalidade: encobrir o privilégio de determinados setores sociais.

De modo que as estratégias de dominação social e de cerceamento dos direitos fundamentais é uma afronta direta à democracia, pois seus defensores ignoram a estreita relação que esse sistema de poder estabelece entre igualdade social e equidade. Cada vez mais os poderes hegemônicos constroem a ilusão de que a sociedade é igual, quando na verdade o abismo entre as classes aumenta cotidianamente.

Nesse sentido, Souza (2009) argumenta que a permanência da desigualdade e do privilégio no país está ligada a dois fatores reproduzidos pelo universo do senso comum: primeiro por um tipo de visão economicista que apresenta fascínio pelos números e 


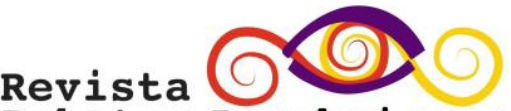 \\ Debates Insubmissos}

estatísticas e segundo pela incapacidade de a sociedade brasileira lidar com os conflitos. Quando conjugados, esses dois elementos encobrem o fato de os cidadãos não serem isolados no mundo, isto é, na verdade todos nós pertencemos a uma classe, muito embora sejamos levados a acreditar que formemos uma coletividade unificada por vínculos de solidariedade e nacionalidade que não podem ser destruídos por interesses particulares.

Ora, num país de incontestável diversidade como o Brasil, o que permite a perpetuação da desigualdade é o trabalho ideológico de naturalização que busca obter das classes dominadas o consentimento e o conformismo em detrimento do privilégio exercido pelos grupos dominantes. Nesse sentido, para que essa estratégia funcione corretamente é necessário que o indivíduo seja separado da sociedade, pois assim o fracasso ou o sucesso no meio social permanecerá dissimulado na ilusão de justiça que envolve os privilégios centrados na meritocracia.

Essa forma moderna de recompensa e prestígio pressupõe que os indivíduos competem entre si com o mesmo grau de igualdade. Assim, o sucesso cabe aos que mais se esforçam e o fracasso aos que não tiveram capacidade e comprometimento com os estudos e com o trabalho intelectual. Mas sabemos que não é isso que ocorre, pois cada classe guarda valores específicos e os sujeitos que delas provém carregam toda uma herança simbólica transmitida, sobretudo, no ambiente familiar. Esse processo de transmissão, portanto, é um processo de reprodução de classe.

Nesse sentido, no caso da experiência brasileira,

[...] para se compreender porque existem classes positivamente privilegiadas, por um lado, e classes negativamente privilegiadas, por outro, é necessário se perceber, portanto, como os "capitais impessoais" que constituem toda hierarquia social e permitem a reprodução da sociedade moderna, o capital cultural e o capital econômico, são também diferencialmente apropriados. O capital cultural, sob a forma de conhecimento técnico e escolar, é fundamental para a reprodução tanto do mercado quanto do Estado modernos. É essa circunstância que torna as "classes médias", que se constituem histórica e precisamente pela apropriação diferencial do capital cultural, em uma das classes dominantes desse tipo de sociedade. A classe alta se caracteriza pela apropriação, em grande parte pela herança de sangue, de capital econômico, ainda que alguma porção de capital cultural esteja sempre presente (SOUZA, 2009, p. 21). 
Por consequência, diferente do que as ideologias dominantes buscam esconder, a sociedade brasileira é marcada pela divisão entre as classes. No entanto, para além dessas duas classes dirigentes classificadas de positivamente privilegiadas pelo sociólogo, o processo histórico de ocupação dos espaços na sociedade brasileira formou uma classe de sujeitos que não possuem nem condições técnicas e intelectuais de imposição cultural, nem privilégios institucionalizados. Souza, provocadoramente a chama de ralé, designando, assim, uma gama de sujeitos que não possuem capital cultural para competir de igual para igual no mercado de trabalho. Em suas palavras, esse epíteto não visa denegrir a imagem dos seus membros, mas sim mostrar o abismo social que partilhamos.

Na leitura que fizemos desse pensamento, acreditamos que essa classe de indivíduos é formada pelos mais variados atores sociais condenados pelo processo de expropriação e acumulação histórica do capital, independente do destino e das escolhas que tenham tomado em suas vidas, se é que tiveram oportunidade para isso. Em síntese, pensamos que os sujeitos que a compõe carregam consigo saberes e práticas ignoradas pelo mundo da técnica, da probabilidade, da estatística e da razão cartesiana que categoriza os indivíduos segundo a linguagem da economia.

Portanto, nesse ponto de nossa discussão, já podemos perceber com mais clareza que a reprodução da desigualdade que presenciamos no aparelho educativo é o reflexo da sociedade em que vivemos. Sociedade que criou "classes" de pessoas com oportunidades diferentes. E nessa altura, trazendo essa constatação para os territórios da Educação do Campo, nos perguntamos: como faremos para superar no nosso meio as disparidades construídas historicamente? Como o trato pedagógico deverá ser pensado quando consideramos que mesmo pertencendo a uma classe específica, os educandos possuem valores culturais subjetivos?

Devemos considerar nas práticas pedagógicas que a concepção de educação necessária a esses contextos, em última instância, não pode ser somente uma educação voltada para o mundo da técnica. Essa precisa ser capaz de fornecer ao indivíduo ampla capacidade de compreensão e interpretação do mundo. Para isso os processos educativos devem estabelecer uma relação imediata entre o sujeito, a instituição educativa e a comunidade. Na Educação do 


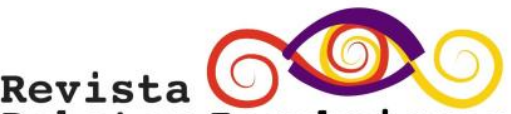 \\ Debates Insubmissos}

Campo esse modo de encarar o trabalho pedagógico é importante porque centra o processo de aprendizagem na história do sujeito, permitindo que ele se torne protagonista de suas falas e ações. Algo que a Educação Rural enquanto paradigma não permite, pois ao educando cabe unicamente o papel de objeto na aquisição do conhecimento.

Nesse sentido, o fortalecimento do campo e do sujeito que nele reside acaba por fortalecer a luta pela educação como um direito humano. No entanto, ela chama atenção para o elevado número de escolas fechadas nesse espaço nos últimos anos, o que configura uma contradição quando constatamos que as discussões em torno da Educação do Campo no mesmo período avançaram. Esse fato é de muita importância para os sujeitos que pesquisam e praticam a Educação do Campo, pois ele é revelador dos desafios a serem enfrentados.

A luta pela efetivação da Educação do Campo como direito, portanto, passa pela necessidade de valorização das comunidades rurais e pela garantia do não fechamento das escolas. Afinal, os sujeitos que residem nesses espaços têm o direito de acesso aos mesmos bens que os nascidos na cidade, normalmente possuem. Acesso à tecnologia, à infraestrutura e a profissionais capazes de lidar com as demandas específicas que surgem nesse universo.

Dessa maneira, Molina (2011) aponta que a prática de se articular na Educação do Campo a escola à vida dos sujeitos e ao cotidiano da comunidade contribui com a construção da autonomia dos educandos. Para ela,

[...] uma das principais características exitosas dessa estratégia, que vincula os processos de ensino-aprendizagem com a realidade social e com as condições de reprodução material dos educandos que frequentam a escola do campo, refere-se à construção de estratégias pedagógicas capazes de superar os limites da sala de aula, construindo espaços de aprendizagem que extrapolem esse limite e que permitam a apreensão das contradições do lado de fora da sala. A escola do campo, exatamente por querer enfrentar, confrontar e derrotar a escola capitalista, não se deixa enredar pelos muros da escola e, muito menos, pelas quatro paredes da sala de aula (MOLINA, 2011, p. 27).

Nessa perspectiva, entendemos que as práticas pedagógicas pensadas a partir do campo possuem características que podem contribuir com a luta pela superação das desigualdades reproduzidas pelo aparelho educativo. A principal delas indica que por ser contextualizada à vida no campo, a tendência é que haja no processo de construção do 
conhecimento a conscientização por parte dos educandos de que a educação é um direito extensivo a todos os cidadãos, independente do território que esse ocupe.

\section{METODOLOGIA}

A prática pedagógica que buscamos descrever neste texto foi desenvolvida pelos estudantes da primeira turma da Licenciatura em Educação do Campo da Universidade Federal dos Vales do Jequitinhonha e Mucuri no ano de 2013 na Escola Família Agrícola de Veredinha - EFAV, localizada na comunidade rural de Gameleira, região do Alto Vale do Jequitinhonha, nordeste mineiro. Essa instituição, cujo funcionamento é pautado na pedagogia da alternância, é gerida pela Associação Comunitária de Desenvolvimento Educacional, Familiar e Agropecuário de Veredinha - ACODEFAV, composta em sua maioria por agricultores e agricultoras locais. Num plano geral, a escola é fruto da mobilização de lideranças comunitárias, sindicais, associações, entidades e sujeitos comprometidos com o desenvolvimento sustentável do semiárido mineiro.

A prática que ora descrevemos foi realizado com as turmas do $3^{\circ}$ ano do EM a partir das lições de Boaventura de Souza Santos sobre a ecologia dos saberes. Para esse sociólogo, essa clave teórica objetiva estabelecer um novo equilíbrio na relação entre o conhecimento científico e os conhecimentos populares. As atividades desenvolvidas, no entanto, podem ser compreendidas também como o desenvolvimento de uma pedagogia da prática. Segundo Santos (1992), práticas como essas são extremamente ricas, pois são delas que surgem as condições necessárias à sistematização da pedagogia que interessa aos trabalhadores (SANTOS, 1992, p. 134).

O ponto de partida para a realização dos trabalhos foi determinado pelas demandas apresentadas pela EFAV, como as dificuldades ambientais frente ao desenvolvimento de tecnologias sustentáveis de fácil aplicação que possam contribuir com o enfrentamento da seca que assola o território ocupado pela escola na maior parte do ano. Assim, em diálogos entre docentes da Licenciatura em Educação do Campo e da EFAV nasceu a ideia de construirmos coletivamente um reservatório de água nas propriedades da instituição, conjugando os saberes acumulados pelos agricultores das comunidades locais com os 
conhecimentos científicos oriundos da geometria espacial e das outras disciplinas do curso de Ciências da Natureza e Matemática da Licenciatura em Educação do Campo.

A prática pedagógica, nesse sentido, foi pensada como uma estratégia de enfrentamento das dificuldades reais daquela comunidade escolar, pois a escassez de água é um dos maiores problemas enfrentados pelos moradores da região, atingindo tanto a agricultura e a pecuária, quanto o consumo humano. As comunidades vizinhas à EFAV convivem com uma solidificada monocultura de eucalipto que ocupa praticamente todas as áreas planas e as chapadas, denominadas pelos agricultores familiares da região de "caixas d'água naturais". Nos diálogos que tivemos com os trabalhadores rurais foi comum ouvir a denúncia de que a silvicultura praticada nos últimos 30 anos é a responsável pelas fortes erosões no solo e pelo esgotamento das áreas de recarga natural, o que vem provocando gradativamente a secagem das nascentes e dos córregos que abastecem as comunidades.

Nesse aspecto, ao considerarmos o testemunho dos agricultores e tendo em vista uma série de outros elementos empíricos favoráveis à construção de um reservatório de água nas dependências da EFAV, arriscamos edificar nas margens disciplinares do Tempo Comunidade, uma prática pedagógica contextualizada às necessidades apresentadas pela escola. Assim, o projeto construído pelos educandos da licenciatura foi apresentado à equipe pedagógica da EFAV em fevereiro de 2013, sendo de imediato incorporado ao calendário letivo e ficando a cargo da monitora das disciplinas de agricultura e matemática a distribuição dos estudantes participantes de cada uma das etapas práticas da construção do reservatório de água.

\section{ANÁLISE}

É importante salientar que na construção da prática pedagógica a autonomia dos estudantes foi de fundamental importância, pois o trabalho coletivo permitiu a efetivação da proposta. Nos territórios educativos da Educação do Campo, essa percepção é importante para a redefinição das relações pedagógicas que buscam estabelecer uma nova função social e cultural para a escola a partir da promoção de atividades didáticas centradas nas situações cotidianas vividas pelos próprios estudantes. 


\section{norstat 0 \\ Debates Insubmissos}

Essa mudança de enfoque busca romper com a velha postura de supervalorização do conhecimento teórico disseminado nas escolas e universidades do país por meio da pedagogia tradicional. Dessa maneira, entendemos que

[...] ao optar pelo estabelecimento de relações horizontais e coletivas entre pesquisador, professor e aluno, estamos tentando, além de desmistificar essa postura, criar novas formas de relação não-hierárquicas, com respeito ao saber advindo da prática, não repetindo, portanto o velho modelo capitalista de produção/distribuição de conhecimento na instituição escolar (XAVIER, 2014, p. 75).

No caso da EFAV, a proposta de construção da caixa d'água, ao se tornar parte integrante do calendário da escola, valoriza as práticas sociais e propicia o trânsito entre as disciplinas, o que acaba fortalecendo a quebra das hierarquias entre os conhecimentos. Nesse campo, ressalte-se que o ato formativo só foi possível de ser ensaiado porque contou com a ajuda de um agricultor que transmitiu ao coletivo de educadores e educandos os conhecimentos necessários à construção, à materialização e à transformação da prática social em uma prática pedagógica contextualizada. Trata-se do Sr. João Godinho, 57 anos, residente na comunidade rural da Lagoa, no município vizinho de Turmalina. Ele ministrou aulas teóricas e participou ativamente da materialização da prática pedagógica.

À princípio, os educandos da licenciatura, os educadores da EFAV e o agricultor discutiram em sala de aula com os estudantes do Ensino Médio os objetivos e os benefícios que a construção de uma caixa d'água com recursos encontrados na própria região, como o bambu, traria ao coletivo. Nesses momentos de discussão teórica e política foram debatidos textos que tematizam a cultura do bambu, como a influência da lua para o crescimento da planta, a melhor época para a colheita do material e outros aspectos relevantes para a construção da caixa d'água.

A essas discussões seguiram outras relativas ao uso sustentável e à preservação dos recursos naturais, pois uma das intenções da prática pedagógica foi promover alternativas que possam ser desenvolvidas pelas famílias dos estudantes da EFAV, haja vista que todos os estudantes da instituição são filhos de agricultores familiares ou tem alguma ligação direta com o campo. 


\section{Revista \\ Debates Insubmissos}

A imagem abaixo ilustra um desses momentos de troca de saberes, indispensáveis a construção coletiva da proposta. Nela o Sr. João compartilha sua experiência com os educandos na sala de aula, mostrando ser possível um novo equilíbrio e uma nova relação entre o conhecimento científico e os conhecimentos populares.

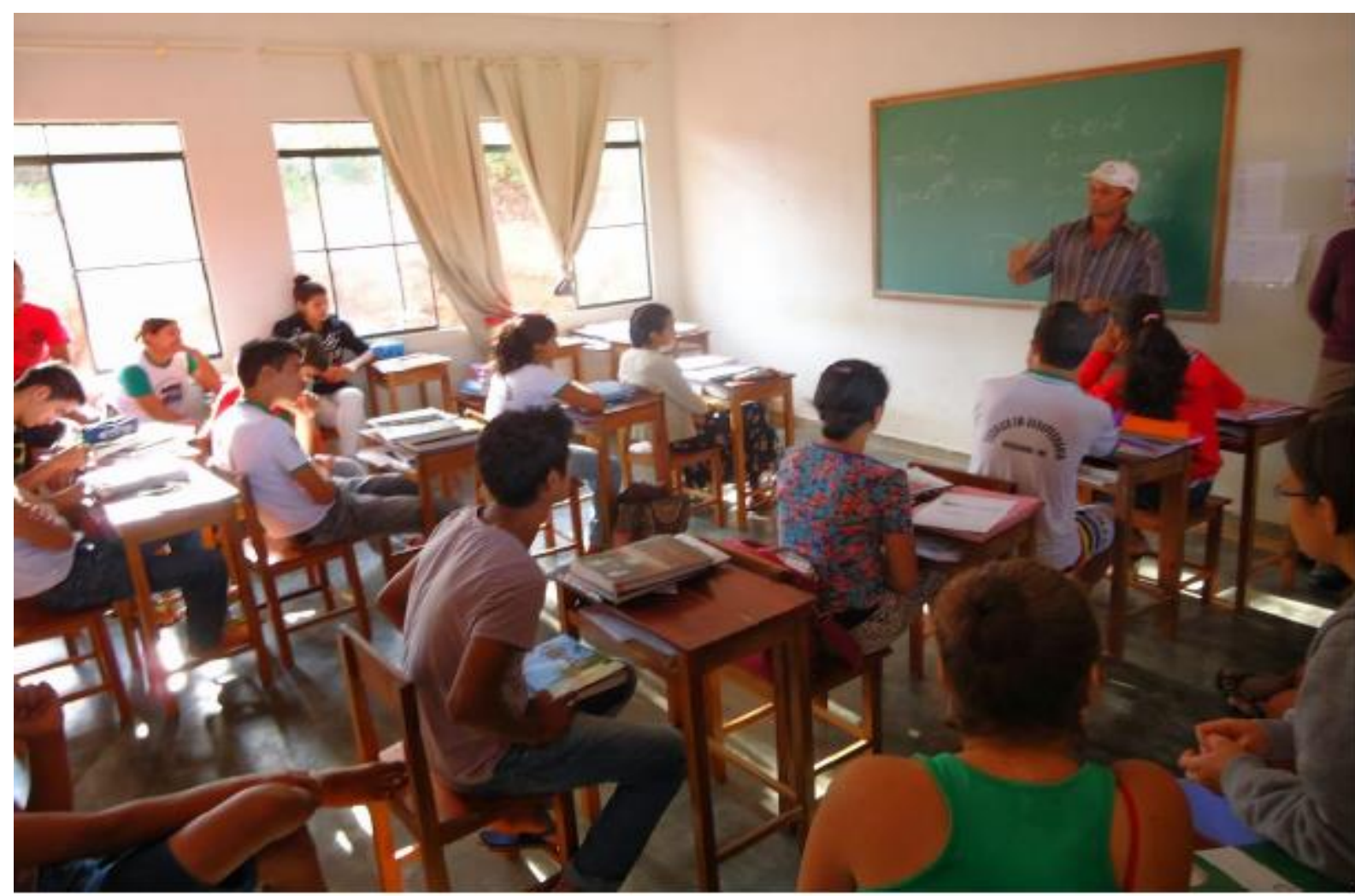

Figura 1: Aula teórica com o agricultor, Sr. João, nas dependências da EFAV

Nessas ocasiões de intercâmbio percebemos nas falas e nos cuidados dispensados ao coletivo pelo agricultor que acompanhou a efetivação dessa prática do início ao fim, o domínio de saberes importantes para a manipulação do bambu que já foram sistematizados pelo conhecimento científico. No que se refere à fase da Lua, por exemplo, Ribeiro (1998) observa que

é no tocante aos vegetais que a Lua tem sido mais observada pelo homem ao longo dos séculos (...). Por isso há uma cultura sobre o tema que, na sua real integridade, está guardada quase que somente na memória dos agricultores mais velhos. No caso do corte do bambu, o período ideal é o da Lua Quarto Minguante, cuja "força" ou 


\section{Revista $0(0)$ \\ Debates Insubmissos}

"período de influência situa-se 3,5 dias antes e 3,5 dias após sua mudança de fase (RIBEIRO, 1998, p. 24).

Cientificamente essa referência temporal para a extração do bambu se explica em função de que nessa fase não há o alinhamento entre o Sol, a Lua e a Terra, o que reduz a força de atração gravitacional, bem como a movimentação dos fluidos na natureza. Para os vegetais isso significa menor presença de seiva e de açúcares concentrados no caule, restringindo o risco de ataque de fungos e de pragas como, por exemplo, carunchos e cupins.

Nesse campo, no decorrer das aulas o agricultor ressaltou que a melhor época do ano para a colheita é aquela em que o bambu está em pleno desenvolvimento, ou seja, nesse período os caules estão mais fortes e, portanto, são mais resistentes para alcançar o objetivo de construção de uma caixa para armazenamento de água. Na imagem abaixo ele repassa ao coletivo os cuidados que devem ser respeitados na escolha do material.

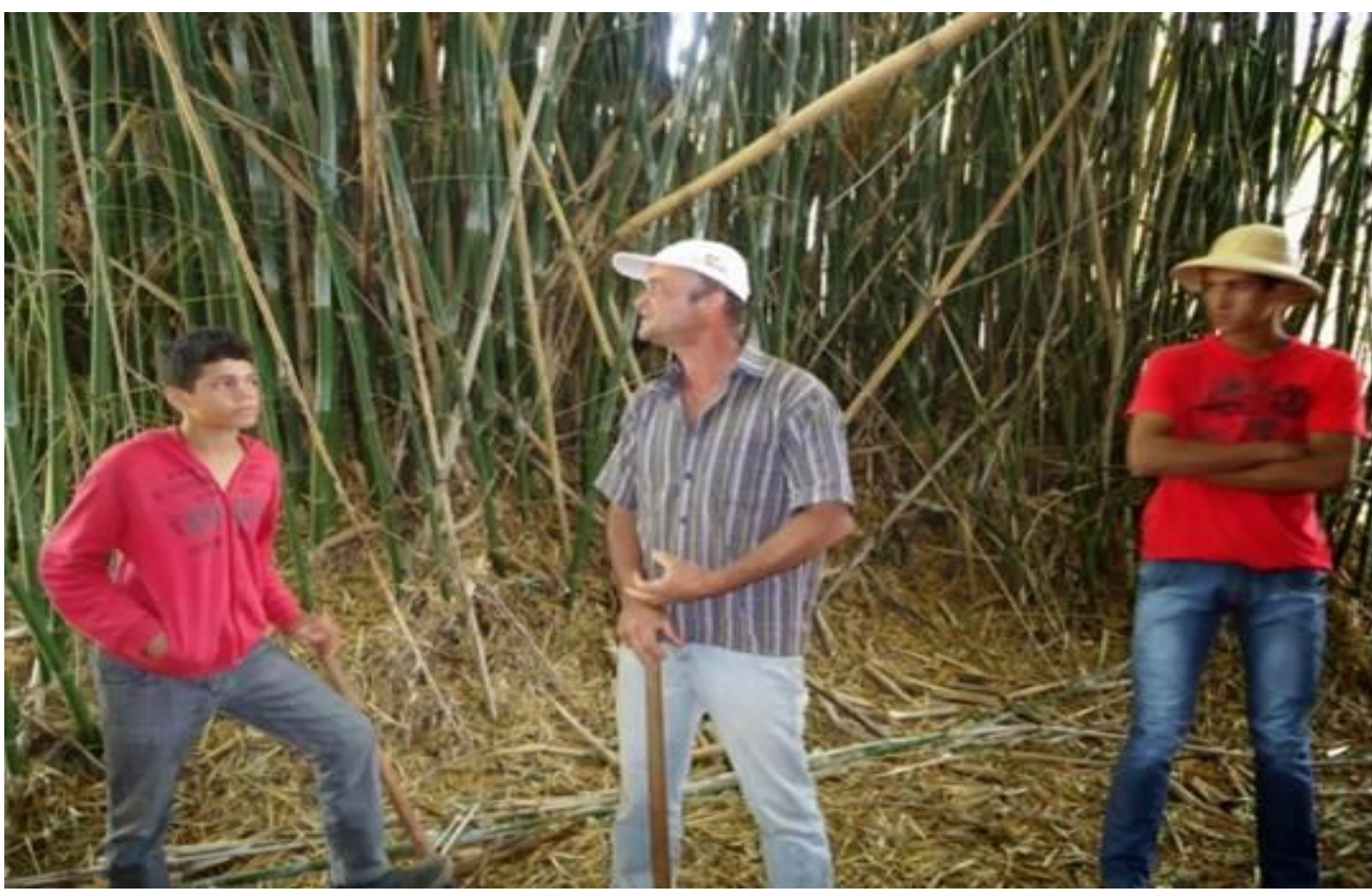

Figura2: Colheita do bambu 
Ainda no que se refere à transmissão de ensinamentos relativos ao grau de maturação da planta utilizada na construção do reservatório, o agricultor explicou que a espécie utilizada bambusatuldóides - deveria ser colhida com a idade aproximada de três anos. No seu entender, o bambu muito novo apresentaria alto teor de umidade e baixa resistência e o muito velho já teria perdido seu poder de elasticidade.

Terminadas as explicações de ordem teórica sobre a cultura do bambu, os estudantes coletaram e transportaram as plantas para o local onde seria construído o reservatório. Já com a mão na massa, o coletivo iniciou a construção das bases da caixa d'água que foi erguida em estilo balaio. Para essa etapa o Sr. João ensinou que a preparação dos bambus deveria ser feita a partir da retirada dos brotos presentes entre os colmos e da montagem da divisão vertical da estrutura cilíndrica de bambu em quatro partes de igual largura. O bambu deveria ser dividido realizando pressão, no sentido da abertura, de igual proporção em ambas as mãos. Porém, ele advertiu que quando a largura das taliscas ficasse desigual, deveria ser feita pressão contrária, ajustando-as novamente na direção de divisão da fibra. É essa importante etapa do processo de construção do reservatório que pode ser notada na imagem abaixo.

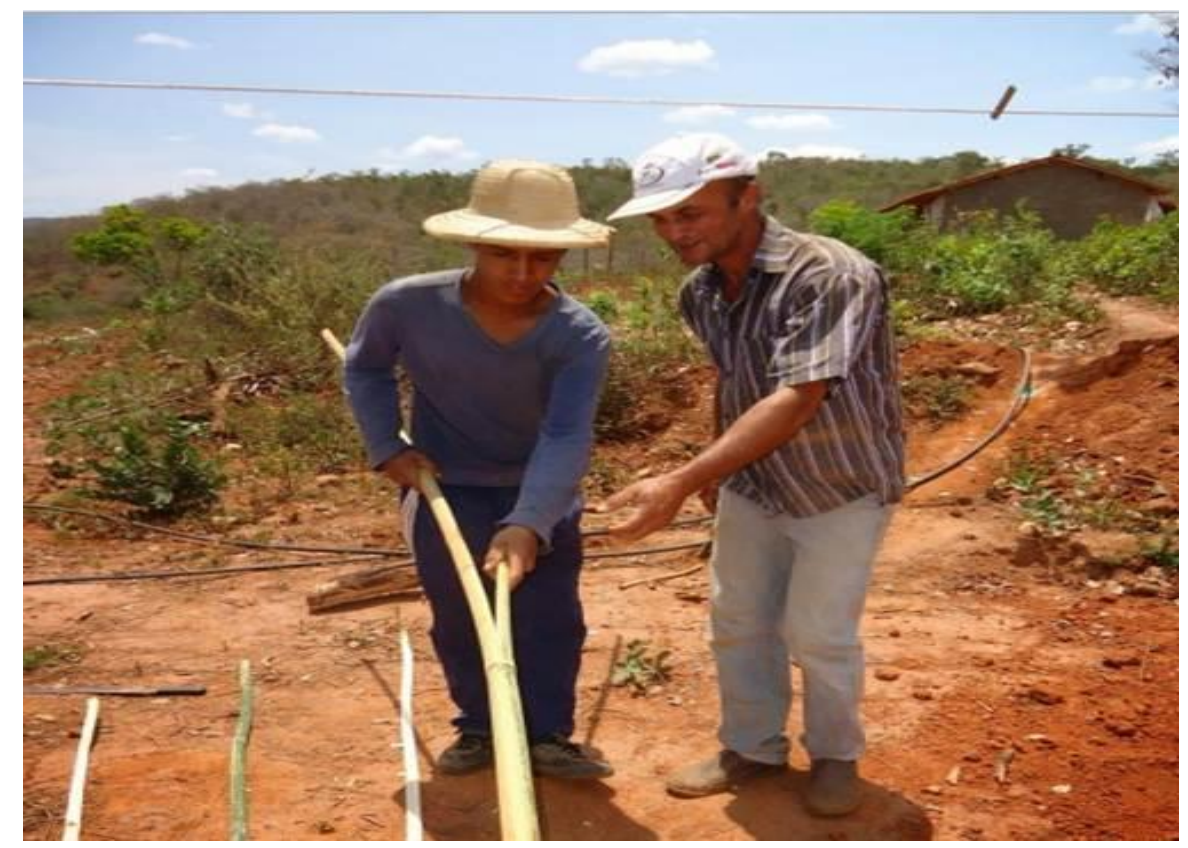

Figura 3: Preparação das taliscas 


\section{Revista \\ Debates Insubmissos}

Outro importante momento da prática foi aquele em que pudemos conjugar as longas e ricas explicações do Sr. João com os cálculos feitos nas aulas de matemática. Como sabemos, as dificuldades de aprendizagem no interior da disciplina de matemática têm muitas motivações, mas grande parte delas decorre da ausência de significado que o conhecimento descontextualizado assume tanto na vida dos educadores quanto na dos educandos. Nesse campo, os marcos legais da Educação do Campo determinam que

[...] os recursos didáticos, pedagógicos, tecnológicos, culturais e literários destinados à educação do campo deverão atender às especificidades e apresentar conteúdos relacionados aos conhecimentos das populações do campo, considerando os saberes próprios das comunidades, em diálogo com os saberes acadêmicos e a construção de propostas de educação no campo contextualizadas (BRASIL, 2010).

Acreditamos que na construção do reservatório os educandos participaram de um processo educativo que concebe a matemática para além da instrumentalização, uma matemática que atende as necessidades reais do sujeito aprendiz ao materializar a natureza abstrata dos conhecimentos matemáticos em objetos reais.

Vale ressaltar, portanto, a importância da prática pedagógica desenvolvida na EFAV como uma estratégia de enfrentamento ao discurso tradicional que vê a instrumentalização como o principal objetivo dos processos formativos. Afinal, práticas pedagógicas como essa têm provado que a produção de significados na perspectiva da educação libertadora necessita de canais de diálogo entre a escola e a vida.

Por essa via, a Etnomatemática chama atenção para a necessidade de se reeducar o olhar sobre as práticas desses grupos, que embora diversos entre si, se "identificam por objetivos e tradições comuns” (D’AMBRÓSIO, 2001, p. 09). E por estarem à margem do ponto de vista da ciência, precisam encontrar espaço dentro da academia, lugar onde sua cultura, identidade, saberes e produção do conhecimento precisam ser reconhecidos e valorizados.

Assim, ao adotarmos a concepção formativa que prioriza o diálogo e o intercâmbio de experiências, iniciamos a construção da estrutura de bambu que suportaria a pressão do volume de água quando o reservatório estivesse cheio. A essa estrutura cuja matriz gerativa utiliza conhecimentos matemáticos, o Sr. João deu o nome de gabarito. 


\section{Revista $\bigcirc$ \\ Debates Insubmissos}

As imagens abaixo demonstram como a conjugação da matemática às realidades locais foi materializada na construção da estrutura. Elas mostram como os estudantes da licenciatura puderam fazer a tradução dos saberes da geometria espacial para os educandos do em um movimento dialógico para além da transdisciplinaridade entre a matemática básica e as demais disciplinas da licenciatura.

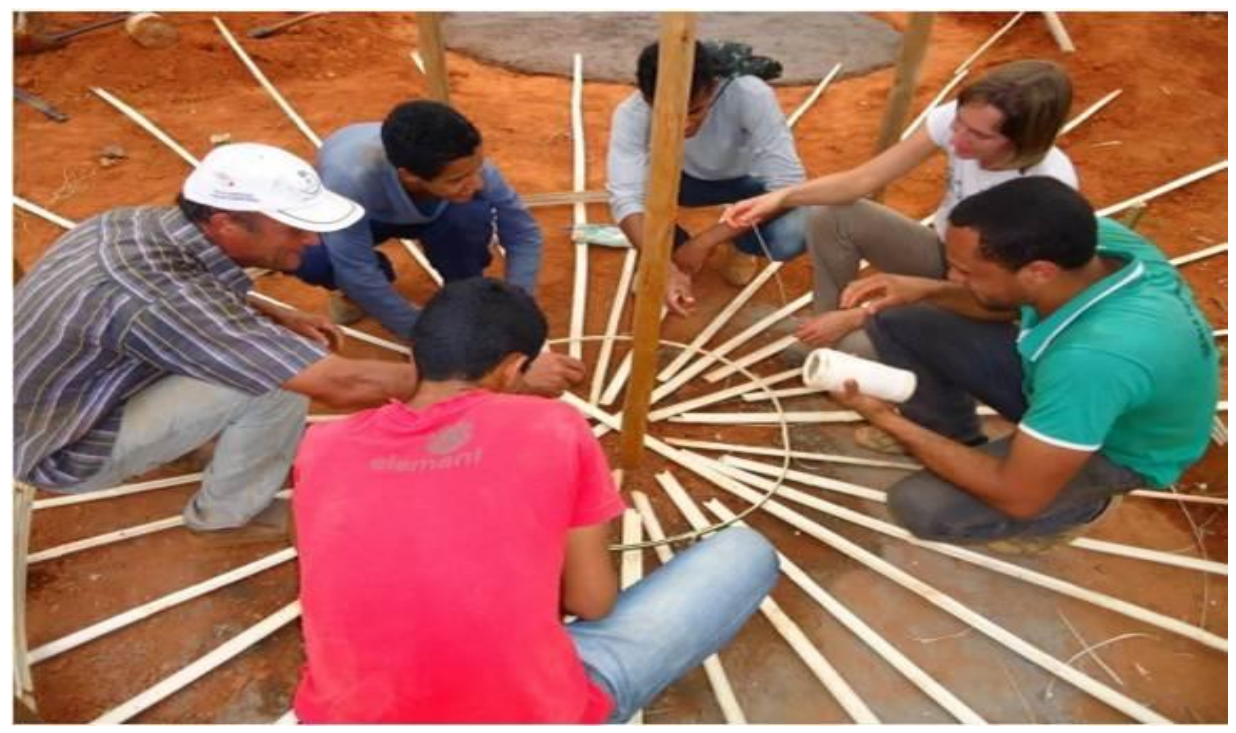

Figura 4: Montagem do gabarito

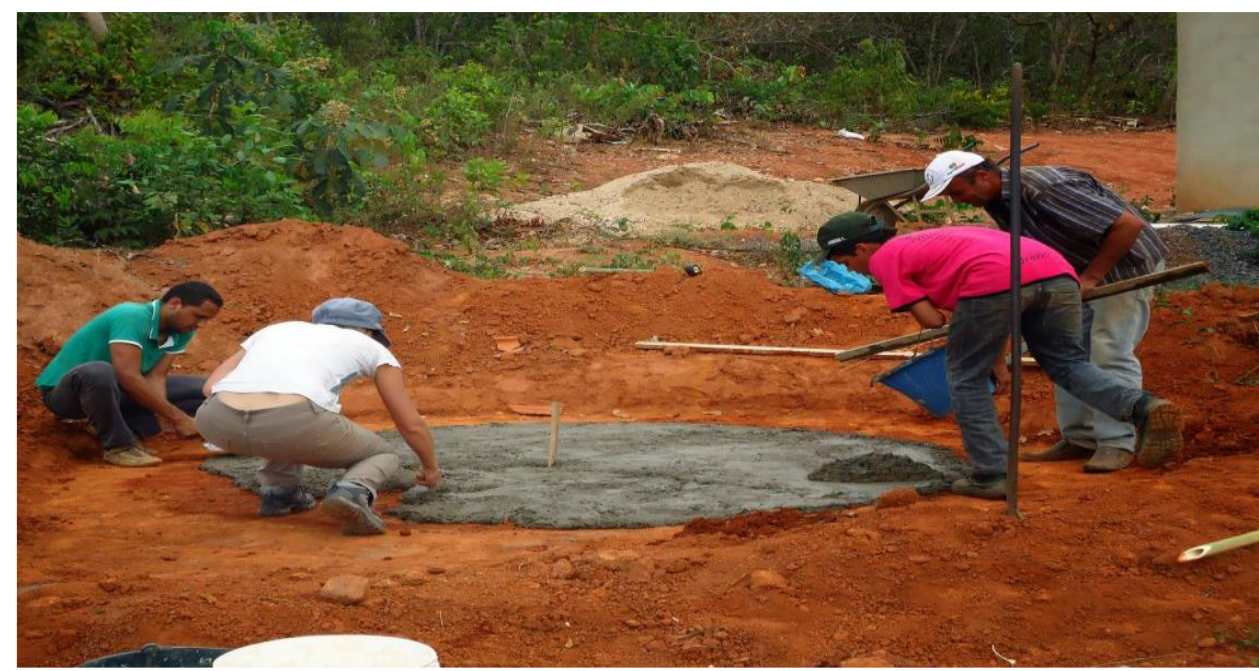

Figura 5: Assentamento do contra piso 
É possível percebermos nessa etapa de demarcação do solo onde foi erguida a caixad'água a interlocução entre as disciplinas que compõem o currículo da Licenciatura em Ciências da Natureza e Matemática ofertadas no TE com os saberes oriundos da experiência transmitida pelo agricultor. Nota-se a aplicação de conceitos básicos de geometria para além das regras e termos técnicos exigidos pela própria disciplina. Os conceitos e definições da geometria, assim como outros elementos básicos da matemática, trabalhados em sala de aula pelos professores em formação da licenciatura compuseram um mosaico capaz de organizar e fazer distinção entre os dados coletados e necessários para cada e em cada etapa da construção do reservatório.

No entanto, em todos os momentos da etapa prática foram utilizados instrumentos matemáticos como o compasso, a régua e o cordão. O ponto, a reta e o plano são elementos primitivos da geometria plana e adicionando o espaço a esse conjunto de entes geométricos, obtêm-se as noções do objeto geométrico construído através de um modelo concreto confeccionado com materiais de fácil acesso pelos estudantes da EFAV, supervisionados pelo Sr. João.

O assentamento do contra piso que formou a base da caixa, por exemplo, é um ponto chave do compartimento que precisa ser milimetricamente planejado, pois o bambu é frágil e não pode ter contato direto com o solo. Assim, é imprescindível evitar toda e qualquer exposição do bambu e reduzir ao mínimo o risco da entrada de possíveis decompositores do material orgânico. Por isso a delimitação da área a ser construída considerou a necessidade de nivelamento do terreno, o que também exigiu a utilização conhecimentos matemáticos na armação da base de concreto preparada na proporção $2 \times 1 \times 1$ (areia x cimento x pedra britada) e com espessura de 5,0. Estas foram as dimensões definidas para a caixa d'água: 1,8 metros de altura, 1,35 metros de raio e 8,47 metros de circunferência. A etapa seguinte do trabalho, então, consistiu na formação da estrutura lateral do reservatório. Como podemos perceber nas imagens abaixo, o agricultor utilizou técnicas de artesanato para revestir a área delimitada com taliscas de bambu. 


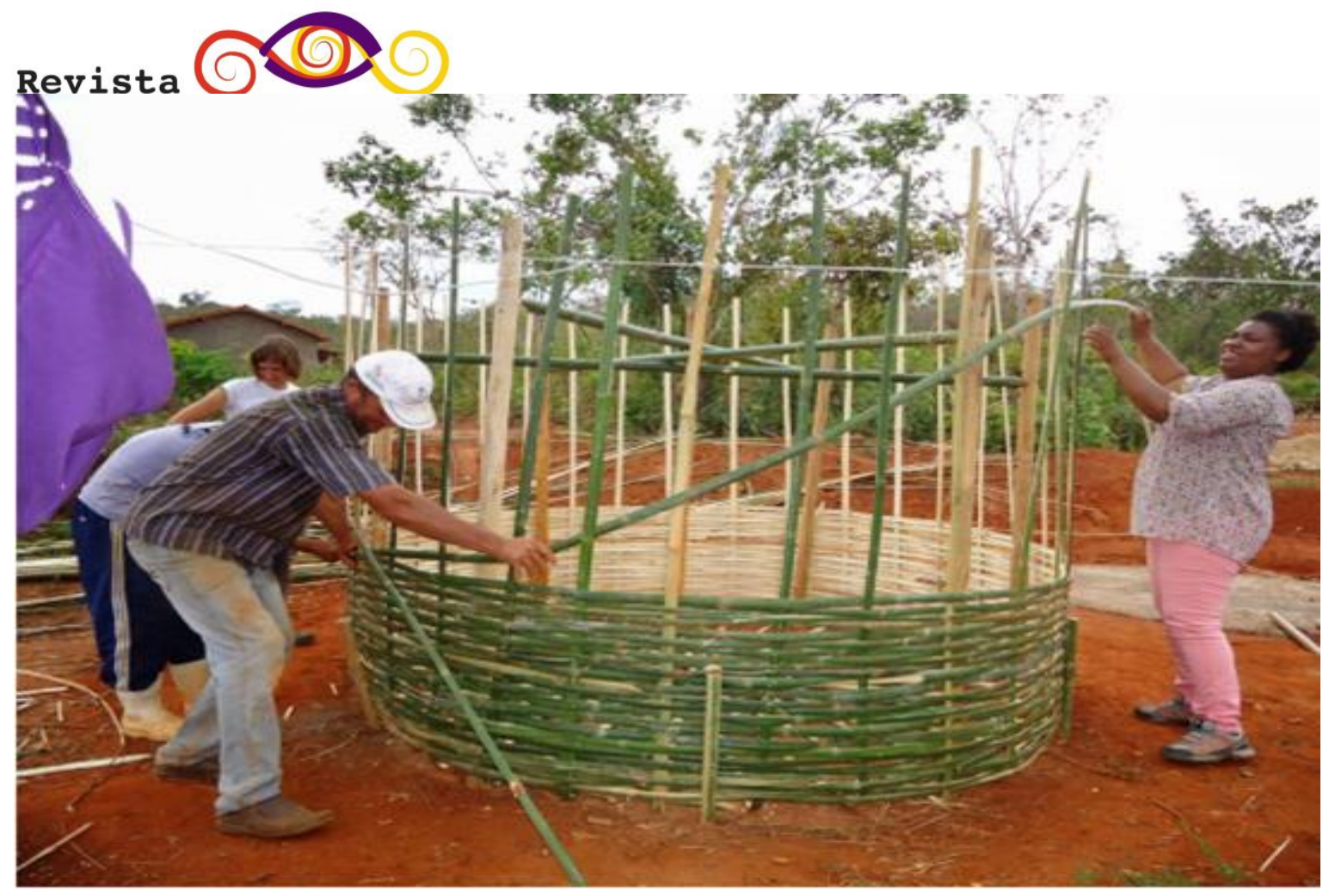

Figura 6: Confecção do balaio

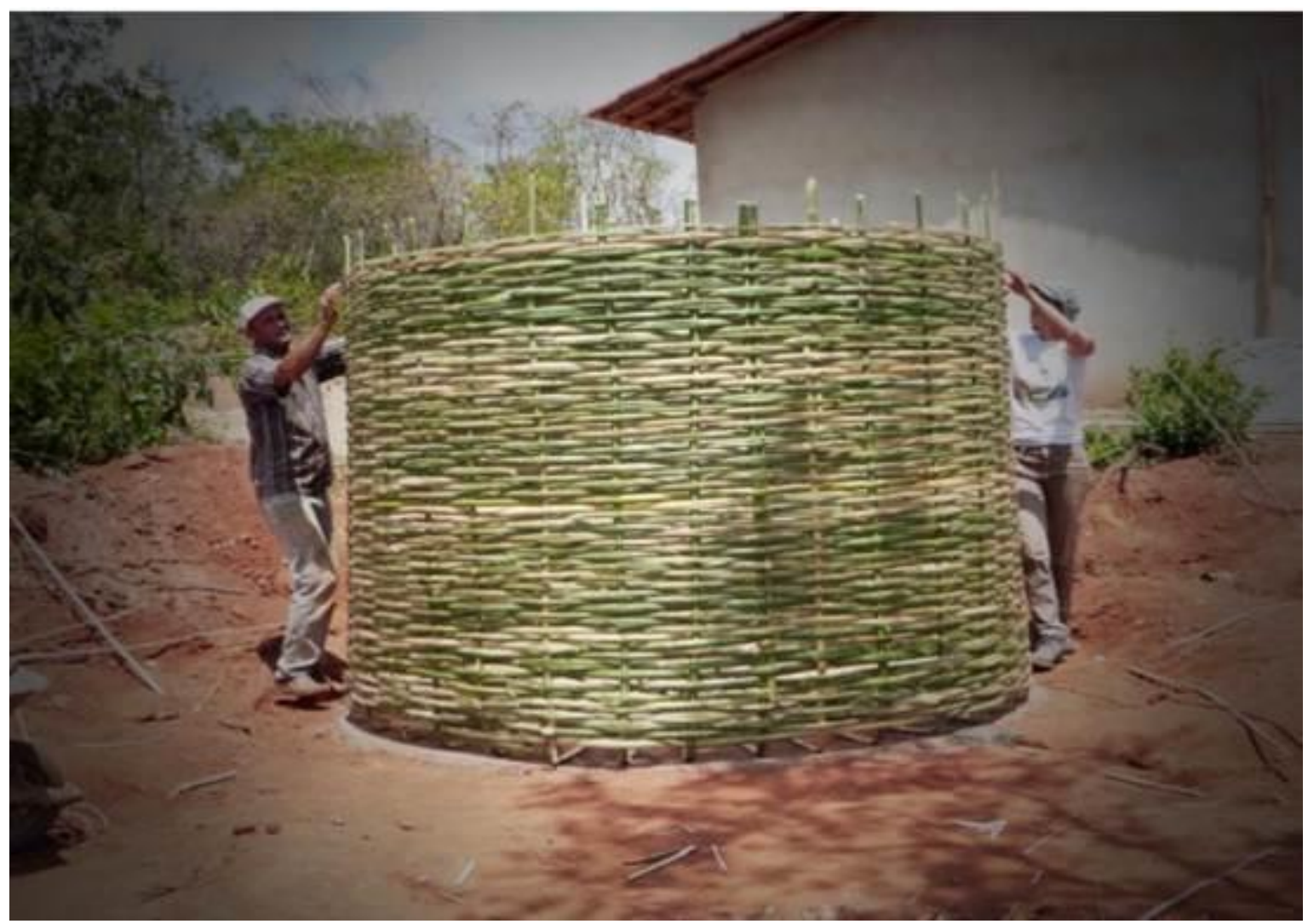

Figura 7: Confecção do balaio 


\section{Revista $\bigcirc$ \\ Debates Insubmissos}

A construção do balaio foi um momento de grande interação, pois todos ficaram ávidos em aprender as técnicas utilizadas pelo agricultor. Com o trabalho coletivo, aos poucos o trabalho manual deu origem ao balaio que serviu de estrutura lateral da caixa d'água.

O próximo passo, então, consistiu na tarefa de revestimento do balaio com uma massa composta de areia, cimento e água. No tocante geral, para a construção do reservatório foram utilizados 03 dias de serviço coletivo, 23 unidades de bambus com comprimento médio útil de 9,0 metros e diâmetro médio de 4,0 cm, $500 \mathrm{~kg}$ de cimento, 1,0 $\mathrm{m}^{3}$ de areia, $0,06 \mathrm{~m}^{3}$ de pedra britada, 01 metro de tubo, 01 joelho e 01 registro em material de PVC. As próximas imagens revelam as etapas finais da construção da caixa d'agua e o produto advindo do trabalho coletivo e contextualizado às demandas apresentadas pela EFAV.

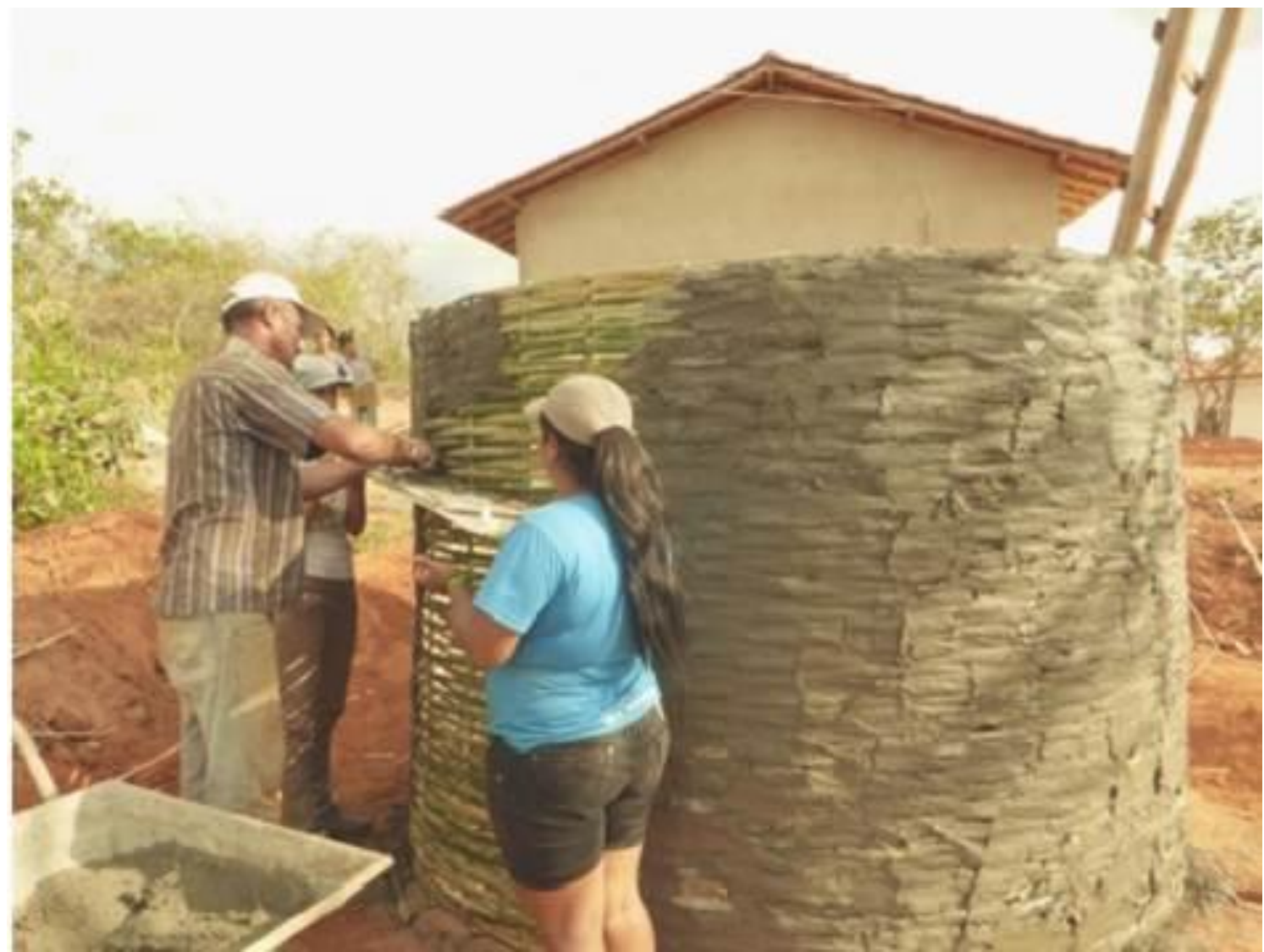

Figura 8: Revestimento do balaio 


\section{Revista ( \\ Debates Insubmissos}

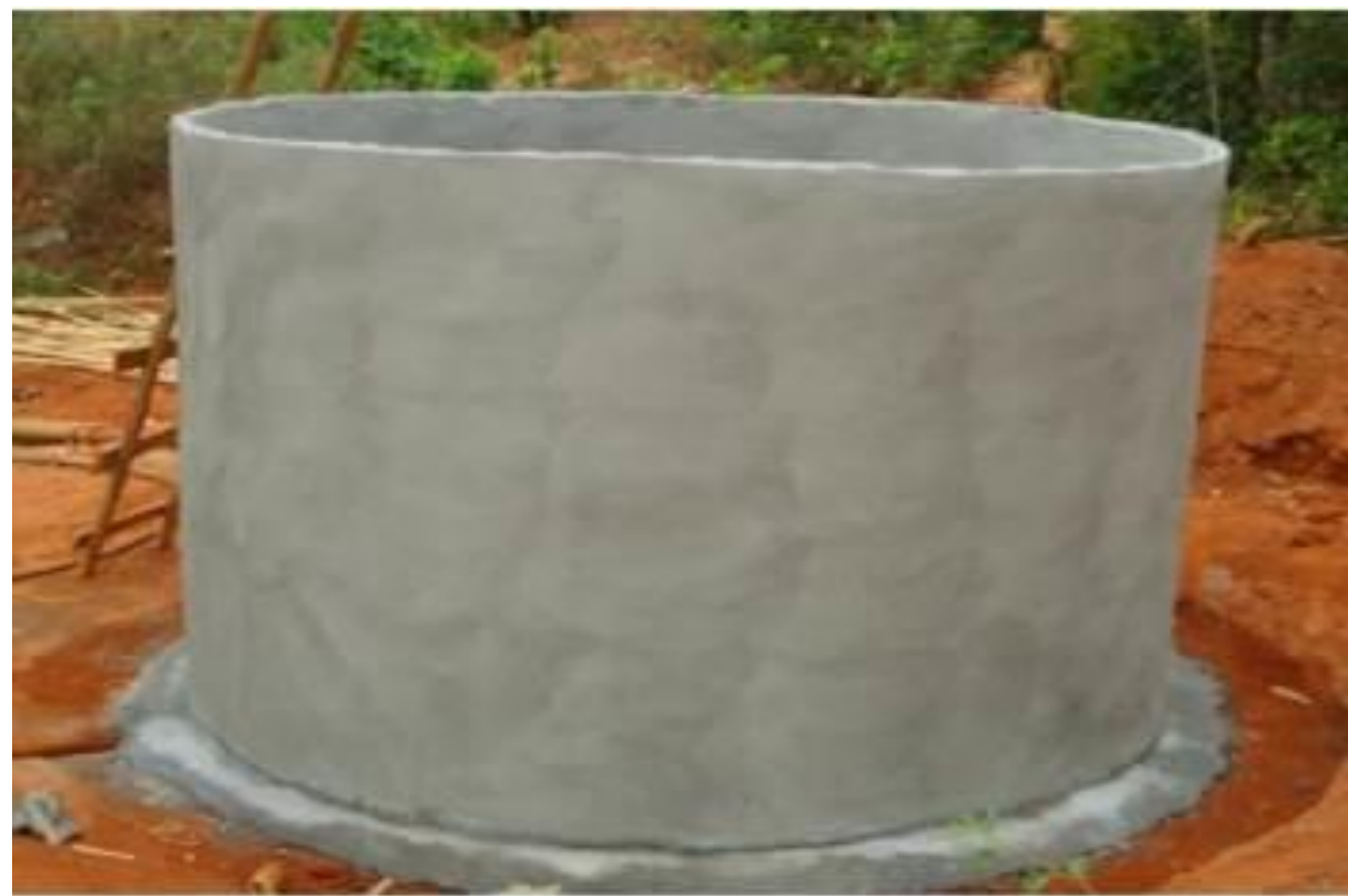

Figura 9: Balaio revestido

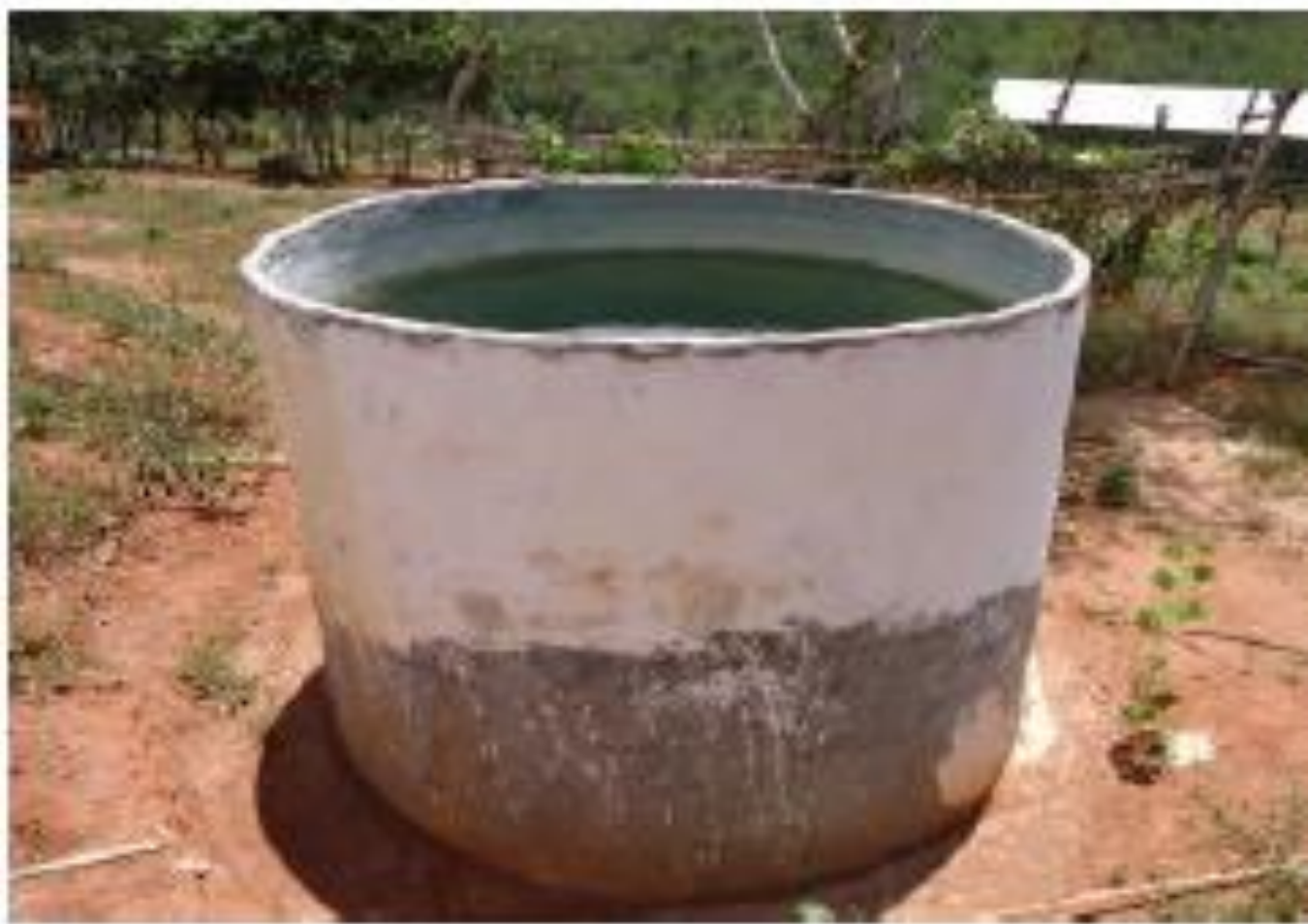

Figura 10: Reservatório em funcionamento 
Os estudos teóricos permitiram construções de hipóteses concretas e reais criando uma conexão com elementos que tornassem possível o desenvolvimento da proposta da caixa com recursos encontrados na região, além da contribuição imprescindível do Sr. João. Nesse momento de soma de experiências teóricas e práticas, a escola traz, dessa maneira, para dentro de seus espaços, o mundo real do qual esses estudantes fazem parte.

Nesse sentido, como buscamos descrever, a experiência de construção do reservatório possibilitou a interação de conteúdos da área de Ciências da Natureza e Matemática com os conhecimentos populares, evidenciando que dialogar e refletir são tarefas de quem protagoniza processos educativos sólidos, não fixos. No caso da pedagogia da alternância, quando os processos educativos são coletivamente construídos, tomam rumos próprios que exigem a sensibilidade criadora, atributo fundamental para dar vida ao desejo de transformação da realidade impedido pelo discurso do modelo único que infelizmente encontramos na maioria dos manuais didáticos.

\section{CONSIDERAÇÕES FINAIS}

A atual conjuntura do debate nacional aponta que o momento é de valorização da diversidade, de reconhecimento da experiência e de superação das desigualdades construídas historicamente no país. Isso porque na sociedade brasileira a simples existência de normas e regulamentos não é garantia para a efetividade dos direitos. Pelo contrário, historicamente as disputas em torno dos projetos de sociedade têm provado que a cidadania plena só será alcançada por meio de muita luta e organização da classe trabalhadora.

No plano da educação os desdobramentos da ideologia dominante são por demais conhecidos e suas consequências estão por toda parte: nos manuais didáticos, nas práticas pedagógicas descontextualizadas, na formação deficitária dos professores, na negação da especificidade camponesa. $\mathrm{Na}$ verdade, como apontamos em nossas argumentações, esses elementos compõem o cenário ocupado pelo velho paradigma da educação rural que sempre concebeu e tratou o sujeito do campo como objeto, e nunca como protagonista dos processos formativos. Uma concepção de território e de existência que necessita ser superada para que o campo seja visto como espaço de produção de cultura e saber, e não apenas de mercadorias. 
Em um plano geral, por ser articulada e protagonizada pelos próprios trabalhadores, a Educação do Campo vem se afirmando no cenário educacional como um instrumento de luta e superação do modelo de sociedade que historicamente negou aos sujeitos do campo acesso aos seus direitos. Nesse movimento, ao contestar as ideias que concebem o espaço rural brasileiro como lugar de atraso, a Educação do Campo desconstrói as ideologias dominantes, gerando fissuras nos discursos hegemônicos que tendem a transformar todas as formas de diferença em desigualdade.

Nos caminhos que percorremos na construção dessa pratica foi possível perceber que entre nós a desigualdade ainda é marcante não só no campo, mas em os todos os aspectos da vida nacional, pois a sociedade brasileira foi construída a partir da ocupação hierárquica dos espaços sociais, de modo que as assimetrias permanecem nas relações de poder, nas práticas socioculturais e nos mecanismos de exclusão reproduzidos, principalmente, pelo aparelho educativo.

Nesses ambientes a desigualdade é acentuada em diversos quesitos, no entanto a relação hierárquica torna-se mais latente na forma como as elites dirigentes valorizaram no decorrer da história o conhecimento teórico dos especialistas em contraposição à prática e à experiência acumulada pelo povo. Nas escolas e nas universidades a naturalização da ideia de superioridade fundou hierarquias entre o conhecimento científico e o popular. Mas como a configuração hierárquica dos saberes não é um dado da natureza e sim uma construção histórica e política, acreditamos que ela pode ser subvertida por meio de uma nova lógica de produção do conhecimento que seja pertinente à realidade dos educandos e das comunidades.

Como vimos, nos territórios da Educação do Campo essa nova visão sobre o conhecimento é propiciada em grande parte pelas experiências acumuladas nos contextos de ensino-aprendizagem mediados pela Pedagogia da Alternância. Esse princípio educativo se constrói a partir de espaços e tempos diferentes daqueles adotados pela pedagogia tradicional, com as atividades partindo sempre do prático para o teórico, do local para o global.

Os processos formativos em alternância são estratégias eficazes na produção do conhecimento tanto no ambiente acadêmico, quanto escolar. Em todos os níveis de ensino a interação entre os saberes articulados pelos especialistas e aqueles advindos da experiência 
dos sujeitos responde pela pertinência dessa metodologia de trabalho como ferramenta de emancipação humana. Neste artigo, quando utilizamos essa metodologia no ensino de matemática nos contextos rurais, notamos que a alternância aliada à etnomatemática foi de grande valia, pois esses dois princípios educativos consideram não só a especificidade cultural dos grupos, mas também a necessidade de fortalecimento das comunidades e de emancipação dos sujeitos.

Dessa maneira, considerando esses dois princípios educativos, compreendemos que a prática pedagógica realizada na EFAV respeitou os elementos indispensáveis à construção do conhecimento nos territórios educativos da Educação do Campo à medida que promoveu a interação, no ambiente universitário e escolar, entre os conhecimentos científicos e os populares. Nesse movimento dialógico, uma série de conhecimentos foram ativados pelos sujeitos em formação. Desse modo, a construção da prática, conforme observa CALDART (2004), provou que

[...] trabalhar com diferentes saberes significa em primeiro lugar não hierarquizá-los, nem considerar que eles são propriedade somente dos educadores, ou dos educandos. Todos somos detentores de saberes e é preciso que o diálogo entre educadores e educandos permita a cada um ter consciência dos seus saberes, além de ampliá-los e diversificá-los por meio da partilha e da produção coletiva de novos saberes (CALDART, 2004, p. 29).

Nessa perspectiva, a construção do reservatório de água nas dependências da EFAV demonstra que a histórica ideia de superioridade entre os conhecimentos é insustentável quando a prática pedagógica se transforma num instrumento de diálogo entre os diferentes tipos e níveis de conhecimento. De modo que no decorrer da pratica que realizamos na EFAV a hipótese que serviu de mote às nossas reflexões pôde ser comprovada na prática: não há saberes superiores, e sim diferentes.

Portanto, este artigo nos permite concluir que essa visão anacrônica e hierárquica do conhecimento que demarcou por longo tempo os currículos e as políticas públicas de formação de educadores pode ser superada se considerarmos a tríade escola-sujeitocomunidade, como ponto de partida para qualquer ação pedagógica que objetive transformar a realidade. 
Contudo, para que isso ocorra, o educador precisa considerar o contexto de vida dos educandos e da comunidade onde a instituição está situada. Nesse ponto, as reflexões que realizamos nos permitem inferir que a atitude interativa pode ser vista como um dos pilares na construção do conhecimento pertinente à realidade dos sujeitos em formação, pois nessa perspectiva o estatuto do conhecimento concebe a experiência como elemento fundante do saber.Podemos dizer que a prática pedagógica descrita e analisada neste artigo se apresenta como uma estratégia de superação do paradigma da educação rural. No contexto do Vale do Jequitinhonha essa perspectiva negligenciou, como em outros espaços do campo brasileiro, os saberes populares como legítimas formas de conhecimento.

Esperamos colaborar com as discussões que buscam contribuir para o fortalecimento da Educação do Campo e com a desconstrução acerca da hierarquização epistêmica historicamente construída, uma vez que podemos constatar que o conhecimento partilhado pelos sujeitos do campo não é exterior aos conhecimentos científicos valorizados pelas instituições educativas. Pelo contrário, ele tem servido de estratégia para que esses sujeitos enfrentem as adversidades cotidianas que todo indivíduo que escolheu viver no campo pode passar.

Restam ainda muitas indagações e caminhos a percorrer. Por ora, buscamos destoar o coro dos contentes e desnudar as verdades que buscam legitimação na narrativa de um só discurso.

\section{REFERÊNCIAS}

ALTHUSSER, Louis. Aparelhos Ideológicos de Estado. São Paulo: Graal, 2010.

BRASIL. Decreto $\mathbf{n}^{\mathbf{0}}$. 7.352/10 - Dispõe Sobre a Política de Educação do Campo e o Programa Nacional de Educação na Reforma Agrária - PRONERA.

CALDART, Roseli Salete. Pedagogia do Movimento Sem Terra. $3^{\text {a }}$ Edição, São Paulo: Expressão Popular, 2004. p.35.

CHAUÍ, Marilena. Brasil: mito fundador e sociedade autoritária. São Paulo: Editora Fundação Perseu Ábramo, 2012.

D’AMBRÓSIO, Ubiratan. Etnomatemática: elo entre as tradições e a modernidade. Belo Horizonte: Autêntica, 2001. 
FREIRE, Paulo. PEDAGOGIA DA AUTONOMIA: Saberes Necessários à Prática Educativa. 25. ed. São Paulo: Saberes Necessários à Prática Educativa, 1996.

PEDAGOGIA DA AUTONOMIA: Saberes Necessários à Prática Educativa. 25. ed. São Paulo: Saberes Necessários à Prática Educativa, 2000.

Pedagogia do oprimido. Rio de Janeiro: Paz e Terra, 2000.

GOMES, Nilma Lino. Ensino Médio: práticas pedagógicas que reconheçam e respeitem a diversidade. Disponível em: http://portal.mec.gov.br/docman/dezembro-2010-pdf/7181-4-6ensino-medio-praticas-pedagogicas-nilma-lino/file. Acessado em: 10/10/2015.

HALL, Stuart. Da diáspora: identidades e mediações culturais. Belo Horizonte: Editora UFMG, 2003.

MOLINA, Mônica C; SÁ, Laís Mourão; BARBOSA, Anna Izabel Costa. A produção do conhecimento na formação dos educadores do campo. In: Em Aberto, Brasília, v. 24, n. 85, p. 1-177, abr. 2011.

MORIN, Edgar. Educação e complexidade. São Paulo: Cortez, 2002.

RIBEIRO, F. Paulo Batista. A influência da lua e os macetes do campo. Ponte Nova: Editora Graff Cor LTDA, 1998.

SANTOS, Oder José dos. Pedagogia dos Conflitos Sociais. Brasil, 1992.

SANTOS, Boaventura de Souza; HISSA, Cássio Eduardo Viana. Transdisciplinaridade e Ecologia dos Saberes. In: Conversações: de artes e de ciências. Belo Horizonte: Editora UFMG, 2011.

SOUZA, Jessé De. A ralé brasileira: quem é e como vive. Belo Horizonte: Editora UFMG, 2009.

UDE, Walter. Educador Social: Dialogo entre universidade e educação básica para formação do professor, In: Presença Pedagógica, Belo Horizonte, v. 20, 2014.

XAVIER, Conceição Clarete. Educação Matemática e Conflitos Sociais. Tese de Doutorado. Universidade de Campinas: SP. 2004.

Submetido em: 21/10/2018

Aprovado em: 08/12/2018 